\title{
Article
}

\section{Reconsidering obstetric death and female fertility in Anglo-Saxon England}

Sayer, Duncan and Dickinson, Sam D.

Available at http://clok.uclan.ac.uk/9709/

Sayer, Duncan and Dickinson, Sam D. (2013) Reconsidering obstetric death and female fertility in Anglo-Saxon England. World Archaeology, 45 (2). pp. 285-297. ISSN 0043-8243

It is advisable to refer to the publisher's version if you intend to cite from the work. http://dx.doi.org/10.1080/00438243.2013.799044

For more information about UCLan's research in this area go to

http://www.uclan.ac.uk/researchgroups/ and search for <name of research Group>.

For information about Research generally at UCLan please go to http://www.uclan.ac.uk/research/

All outputs in CLoK are protected by Intellectual Property Rights law, including Copyright law. Copyright, IPR and Moral Rights for the works on this site are retained by the individual authors and/or other copyright owners. Terms and conditions for use of this material are defined in the policies page.

\section{CLoK}

Central Lancashire online Knowledge www.clok.uclan.ac.uk

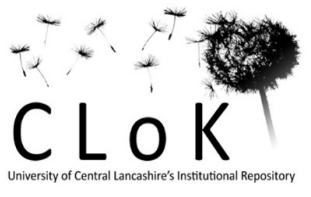




\section{Reconsidering obstetric death and female fertility in Anglo-Saxon England}

\section{Duncan Sayer \& Sam D. Dickinson}

To cite this article: Duncan Sayer \& Sam D. Dickinson (2013) Reconsidering obstetric death and female fertility in Anglo-Saxon England, World Archaeology, 45:2, 285-297, DOI: 10.1080/00438243.2013.799044

To link to this article: http://dx.doi.org/10.1080/00438243.2013.799044

\section{Copyright (c) 2013 The Author(s). Published by Taylor \& Francis.}

曲 Published online: 14 Jun 2013.

Submit your article to this journal $\asymp$

III Article views: 5428

ai

View related articles

Citing articles: 4 View citing articles $๘$ 


\title{
Reconsidering obstetric death and female fertility in Anglo-Saxon England
}

\author{
Duncan Sayer and Sam D. Dickinson
}

\begin{abstract}
Little has been written about female fertility and maternal mortality from an archaeological perspective. Typically debates focus on the physical aspects of childbirth, ignoring an obvious truth: the biggest single cause of death for women was childbirth. Whether death took place as a result of mechanical malpresentation, infection or blood loss, the root cause was undeniable. In this article we argue that post-mortem extrusion is improbable and that young infants and women found buried together are likely to have died together. However, most deaths would not have been simultaneous and so we build on demographic data to conclude that the early Anglo-Saxons engaged institutions which controlled female sexuality. Late marriage, cultural and legal taboos and an emphasis on mature fertility acted to limit the probability of death; however, the risk to the individual was real and each funerary party was the agent that constructed death ways to manage loss.
\end{abstract}

\section{Keywords}

Taphonomy; coffin birth; maternal mortality; fertility; special burial.

\section{Introduction}

Our understanding of Anglo-Saxon burial practices has been revolutionized in the last decades, developing from an examination of artefact typologies and ethnicities into an established exploration of the social experience. In part this has grown out of an interest in mortuary archaeology, memory and deviant burial (Lucy 1999; Price 2010; Reynolds 2009; Williams 2006). In parallel, archaeological interpretation has developed sophisticated gender archaeologies investigating infant agency, life courses and the human experience (Crawford 2007; Gilchrist 2012). It is within this context that the discovery of a pregnant woman buried with a rich array of grave goods on the margins of a large early Anglo-Saxon cemetery provided new insights into female fertility, pregnancy and the life course (Sayer, Mortimer and Simpson 2011).

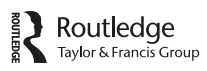

World Archaeology Vol. 45(2): 285-297 The Beginnings of Life ISSN 0043-8243 print/1470-1375 online http://dx.doi.org/10.1080/00438243.2013.799044

(C) 2013 The Author(s). Published by Taylor \& Francis.

This is an Open Access article. Non-commercial re-use, distribution, and reproduction in any medium, provided the original work is properly attributed, cited, and is not altered, transformed, or built upon in any way, is permitted. The moral rights of the named author(s) have been asserted. 
Oakington is the site of an early Anglo-Saxon cemetery in Cambridgeshire (AD 450-700). Excavated in June 2011, grave 57 contained a woman with a descended foetus across her pelvic cavity, a position unlikely to result from post-mortem extrusion. She was aged between 25 and 30, had congenitally absent teeth and occupational wear on her hands and feet (Buikstra and Ubelaker 1994). She was buried supine in full dress with a cruciform brooch and two small long brooches. The foetus lay low and transverse across her pelvis, which was probably the cause of this double fatality (Fig. 1). Even today transverse lie pregnancy is a dangerous malpresentation for both mother and foetus, almost always resulting in Caesarean section (Simm 2007). There are other examples of women with in situ foetuses from Anglo-Saxon cemeteries. However, in archaeology the dominant interpretation for extruded and partially extruded foetuses is currently a phenomenon known as coffin birth: the post-mortem extrusion of a foetus into the grave (Lewis 2007: 35). The recognition that this taphonomic process is in fact improbable under burial conditions and that death from childbirth was a major cause of female mortality allows not only an appropriate interpretation of the mortuary context, but also an exploration of female fertility as a significant and embedded phase in the adult life course.

Calvin Wells was certain that the only way to identify death in childbirth was by direct association, where the foetus is found in the pelvic canal (Chadwick Hawkes and Wells 1975; Wells 1978). However, maternal mortality in the Middle Ages may have been the cause of up to 50 per cent of young female fatalities (Högberg et al. 1987) and is the cause of 30-40 per cent of deaths in the modern developing world, particularly where emphasis is placed on adolescent and early adult fertility (Marai Bhat 2002; Wilmot and Gemmill 2012). Building on this position, we will argue that examples of pelvic situated and extruded foetuses from Anglo-Saxon cemeteries were likely to have been caused by death in childbirth and also that neonates found in double graves may have been the result of maternal mortality because death does not have to result from mechanical means: infection, haemorrhage, sepsis and eclampsia can cause infant and female fatality up to forty-two days post-partum.

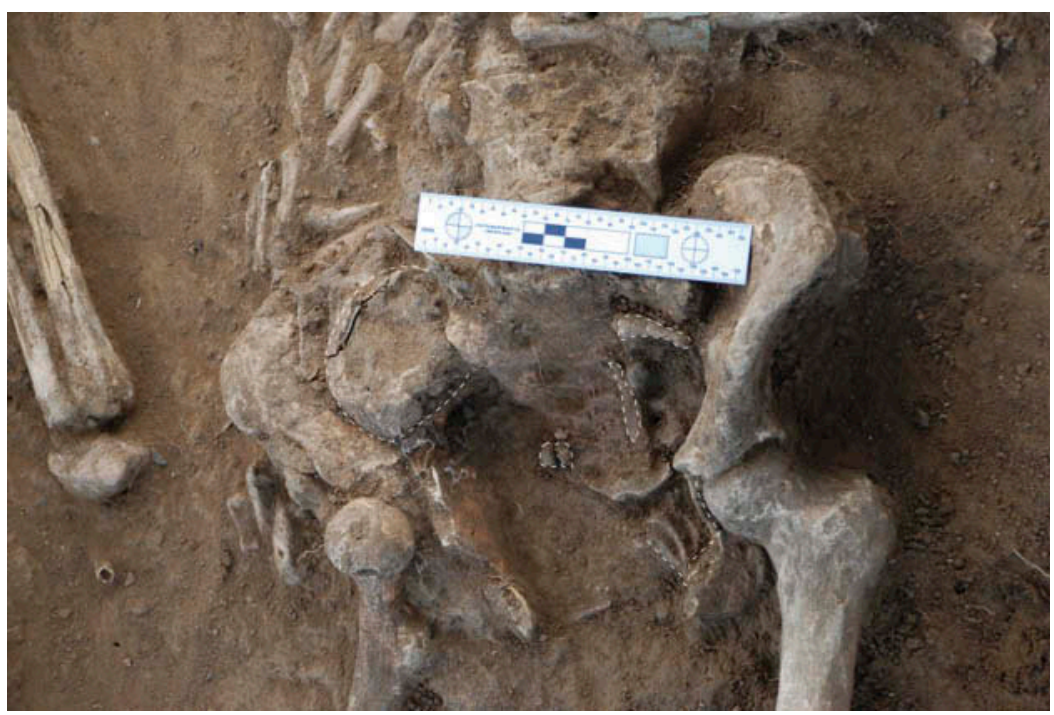

Figure 1 Skeleton 57 from Oakington; note the descended, transverse lie foetus in her pelvis. The white dotted line shows some of the in situ foetus. 


\section{Archaeology and maternal mortality}

Post-mortem extrusion, it is speculated, takes place forty-eight to seventy-two hours after death because the formation of decomposition gases creates an increase in intra-abdominal pressure, causing the uterus to prolapse, resulting in post-mortem delivery (Smith 1955: 25). Coffin births have been described in modern forensic cases but not as the result of decomposition (Schulz, Püschel and Tsokos 2005). For example, in one fire-related death a foetus was found outside the mother's body, reportedly caused by the initial heating and subsequent shrinking of the uterine wall (Vennemann et al. 2008). Another case of coffin birth involved foetal expulsion after heroin overdose; labour had onset so the foetus was head down (Schulz, Püschel and Tsokos 2005; Vennemann et al. 2008). In this case the heroin may have induced the early stages of labour. The key diagnosis is the dilation of the cervical canal and for foetal extrusion to take place unaided a significant degree of dilation prompted by antemortem contractions is required. Plausibly uterine contractions could be 'caused by the onset of rigor mortis' (Schulz, Püschel and Tsokos 2005: 275); however, this is in fact an inhibiting factor because of the restriction of tissue. Relying on the decomposition process to create forward momentum also presents a problem. In an earthen grave the cadaver is surrounded by soil, around and on top of the stomach, pelvis and between the legs, a situation which would certainly prevent the extrusion of an intact, fully articulated foetus. As a result, the unusual taphonomic situation required for coffin birth may be restricted to coffin-like cavities. Other taphonomic processes are caused in the coffin environment because of the absence of soil. When neck ligaments are no longer robust a skull may move, nudged by water or gravity (Emory and Wooldridge 2011: 22). However, putrefaction takes longer than forty-eight to seventy-two hours and extrusion would have to overcome an un-dilated, un-plastic, cervical canal, while the foetus was itself decomposing. As a result, coffin birth would be extremely unlikely to occur within an archaeological burial even inside a coffin-like cavity.

Calvin Wells' conservative approach to maternal mortality derives from the certainty of identification (Chadwick Hawkes and Wells 1975; Wells 1978). At St Nicholas Shambles, a medieval site in London, he identified a woman with cephalo-pelvic disproportion; she died with the foetus lodged within the birth canal where it remained for burial (Wells 1978). However, female skeletons with a foetus within the pelvic cavity, birth canal or in obstruction between their legs are rare in the archaeological record (Lewis 2007: 34). But death because of childbirth was not rare in the past (Högberg et al. 1987). An infant who died singularly may have been placed inside the grave of a contemporary adult, as seen in post-medieval Anglican practice, and sometimes infants were passengers in the coffins of unrelated adults, as in two examples from St Pancras, London (Emory and Wooldridge 2011: 86; Roberts and Cox 2003: 255). These examples are from urban and early modern contexts; populations in pre-industrial, rural, family-based societies, like Anglo-Saxon England, were small and dispersed so deaths were less frequent and less likely to coincide: a situation which significantly increases the probability that a young infant and adult woman found in the same grave were associated.

\section{Double obstetric calamity in early Anglo-Saxon England}

At a superficial glance grave 57 at Oakington fits a recognized pattern of infant and woman double burial seen at other large early Anglo-Saxon cemeteries (Crawford 2007; Lee 2008). Lee identified a series of burials from Beckford, Barrington and Apple Down where women with 
skeletal trauma, leprosy and swollen limb bones were buried with infants or near children. She argued that this presented a 'liminal' location, reserved for children and impaired individuals unable to carry out the duties of adults; both, she proposed, were the recipients of a diminished legal status (Lee 2008: 28-36). Crawford developed this position, suggesting that the physically impaired, rich females from Barrington and Castledyke were accompanied by infants to add value to the grave assemblages, and that those infants had no agency or value as bodies (Crawford 2007: 90). Unfortunately, these studies pick only specific burials. Indeed, when illustrating the association of children and disabled individuals, Lee described the burial of a child and woman with a 'terminal illness' from Flixborough (Lee 2008: 31). Both individuals are dead and so both suffered from terminal circumstances, as did the whole mortuary population; the prevalence of disabling and terminal conditions is unknowable, as is the effect of a 'terminal illness' on the individual lived experience (Wood, Milner and Harpending 1993). Grave 57 from Oakington may have been physically distinct but the skeletal evidence indicates that she was not diminished in her contribution to adult society and had worked enough to alter her body permanently: she had wear patterning on her teeth from working activities like chewing leather, occupation markers on her left distal metacarpus and squatting facets (which may be inherited). At Apple Down infants were not separated off into marginal zones but were located right in the heart of the cemetery, adjacent to the older individuals and the richest graves; the individuals with skeletal trauma were located throughout the cemetery (Fig. 2) (Down and Welch 1990). These infants were not dangerous or subsidiary burials but were core to the organization of the Apple Down mortuary population. As a result we must consider an alternative interpretation for the marginal presentation of grave 57 on the edge of the Oakington cemetery.

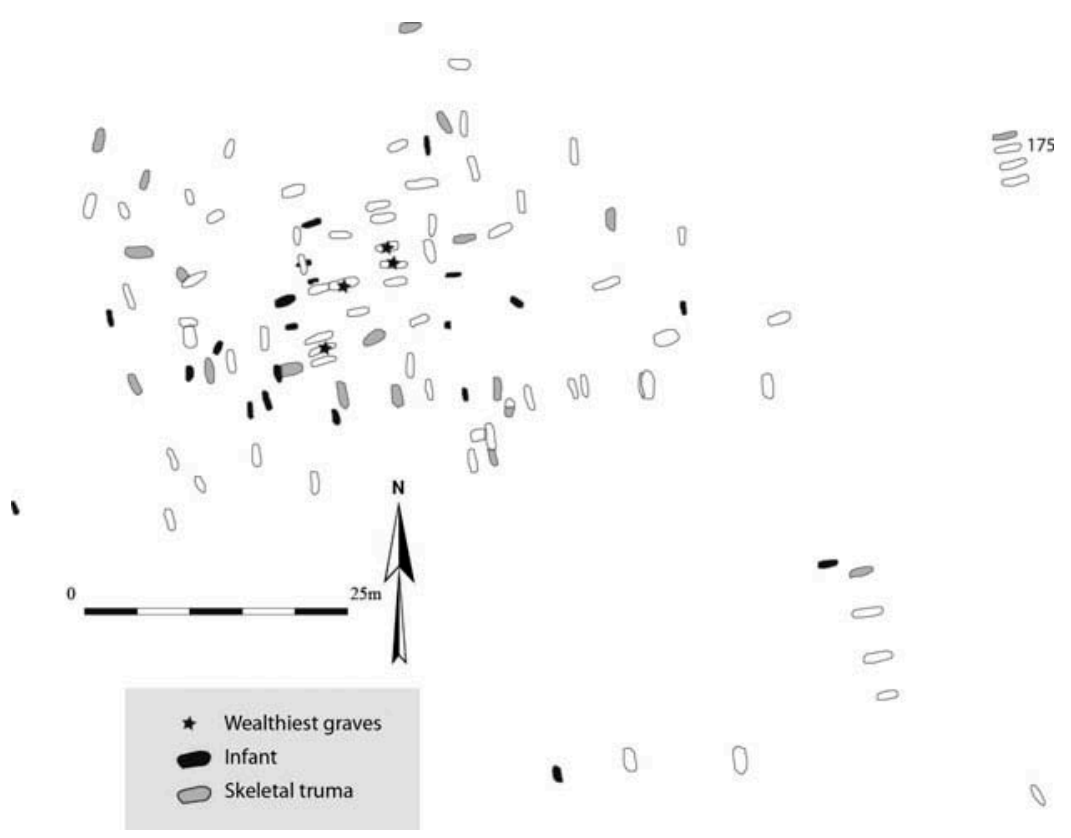

Figure 2 The Inhumation graves at Apple Down highlighting the wealthiest graves, infant graves and those which show evidence of skeletal trauma (excluding osteoarthritis) (after Down and Welch 1990, fig 2.4) 
Early Anglo-Saxon cemeteries often include double graves comprising an infant and woman (Crawford 2007; Stoodley 2002) but many contain older infants and children who could not have died at birth (grave 18 from Barrington, Cambridgeshire, for example, contained a child aged 3 and an adult woman) so are not easily compared with grave 57 at Oakington (Malim and Hines 1998). However, there are a number of other burials with foetuses or neonates which are good cases for double obstetric deaths and parallel the Oakington grave.

\section{In utero double burials}

At Abingdon I, a pregnant woman aged 15-20 was interred on the edge of the cemetery, her grave including beads, a bucket and three brooches (Leeds and Harden 1936). As with the burial at Oakington, she was interred with a different orientation from the rest of the cemetery but among other furnished graves. Burial 110 from Dover, Buckland, included a wealthy female aged 20-30 with an undescended foetus, its head in the birth position. She was interred in the middle of the cemetery, surrounded by similarly seventh-century graves. No pathology was listed (Leeds and Harden 1936; Powers and Cullen 1987: 197-8). Apple Down grave 175 contained a foetus in the woman's pelvic cavity; she was 35-40, had osteoarthritis in her hip and was buried on the edge of the cemetery in a small group of unfurnished graves (Down and Welch 1990).

Great Chesterford 32 was the grave of a young woman aged 15-25 with the bones of a thirtytwo-week foetus in her pelvis. She was buried flexed on her right-hand side with both knees drawn up. Her grave goods included an iron ring-headed pin, a knife and a nail (Evison 1994: 96). Grave 32 was located in a cluster of burials on the edge of a small plot of graves all oriented in the same south-north direction. She had Schmorl's Nodes affecting the eleventh and twelfth thoracic vertebrae and the second and third lumbar vertebrae. Schmorl's Nodes are a common spinal condition and may not be symptomatic but may have been caused by lifting and work (Waldron 1994: 58, 64). A second burial, 127, was of a moderately furnished female, aged 25-35, with a descended foetus lodged within her pelvis. She was buried with a knife, two disc brooches, an annular brooch mould, five beads, an iron pin and iron ring (Evison 1994: 109). The laminae on her fourth and fifth lumbar vertebrae were fused, a congenital anomaly, but her movement was probably unaffected (Waldron 1994: 58, 64).

At Castle Dyke, Barton-on-Humber, a female aged 35-40 carried in-utero a thirty-seven-week foetus, she was positioned in grave 146 with her right hand over her extended abdomen. The skull of the foetus; was on the left ilium in the birth position but was undescended. The excavator believed she was pregnant when buried and certainly the position of the arm and foetus imply this, even with the possibility that the foetus was placed on top of the woman during burial (Drinkall and Forman 1998: 77; Lewis 2007: 35). Burial 146 showed no evidence of pathology, was unfurnished and placed in a cluster of similar burials oriented south-north. Burial 147, of a male aged 45+, was deliberately placed over 146, on an east-west orientation, unusual for that area of the site.

Worthy Park grave 26 contained an 18-30-year-old female buried supine with a foetus between her thighs (Chadwick Hawkes and Granger 2003: 33). Grave 26 was unfurnished and positioned in a group of similar burials; the adult showed evidence of osteocondritis on the base of her left first metatarsal, chiefly caused by trauma to the foot associated with carrying heavy weights, digging or ploughing (Wells 2003: 168). The Worthy Park grave has been described as an example of coffin birth (Lewis 2007: 36). However, this is unlikely because the foetus's body was extended, with a slightly bent neck, not a position that post-mortem exudation 
could reproduce either within the soil or on an open grave base. More likely this foetus and mother died in childbirth and were interred together as one, foetus caught up in obstruction and laid out in the grave with its feet within the birth canal. This is not improbable and animals are occasionally found with a partially extruded foetus; a cow at Gussage All Saints was excavated with the front end of a calf still in its uterus (Wainwright 1979: fig. 109).

What is extraordinary in all of these Anglo-Saxon cases is that the foetus was left in position, a cultural choice not continued in the Middle Ages. The Council of Canterbury (AD 1236), the Council of Treves (AD 1310), and a fifteenth-century Augustinian canon required the unbaptized, unborn foetus to be cut out (Anderson and Parfitt 1998; Gilchrist and Slone 2005, 71) (ecclesiastical law may not, of course, describe actual behaviour and neonatal children were identified in Gilchrist and Slone's monastic sample (Gilchrist and Slone 2005)). However, with the discovery of a woman and in-utero foetus at the eighth-century Christian site, St Marys Road, Southampton, it seems this practice was not an Anglo-Saxon one (Garner 2011). Because separation was not the norm, examples of young infants in women's graves may also have been examples of maternal mortality.

\section{Infant and woman double burials}

The most common types of double burials are: child and woman (22 per cent), man and woman (19 per cent) and infant and woman (12 per cent) (Stoodley 2002). Stoodley argued that double burials may be amuletic, rather than of family members, and took place when two individuals died in close proximity. This theory was further explored by Crawford who suggested that infants are found in special burials, rich graves or the graves of the physically distinct, indicating they were human sacrifices (Crawford 2007: 89). Some adult burials may well be examples of sacrifice, but it is striking that, from the forty-six cemeteries Stoodley sampled, only one male was found buried with an infant, an exception which implies a strong connection between infant/adult double burial and female fertility. But this association need not be the result of human sacrifice because human fertility carries it its own risk of mortality.

Infants are found in graves with women, but the best cases for double death may be with younger infants. As mentioned earlier, maternal mortality does not have to result from mechanical means and haemorrhage, sepsis and eclampsia can cause fatality up to forty-two days postpartum. An infection related to delivery or severe haemorrhaging could easily have killed a woman in Anglo-Saxon England. Similarly, newborns can develop infections and other conditions once outside the womb. As a result, many women found adjacent to young infants may be candidates for maternal mortality. Some examples have been found in large, well-excavated sites; for example, Barrington graves 13 and 84 contain a woman and an infant. Grave 13 was a rich burial with a cruciform brooch and two small long brooches, she had a new-born infant laid on her chest and shoulder, but as at Oakington, she was an outlier to the cemetery (Duhig 1998: 48). She was aged around 25 but showed no evidence of pathology. By contrast, grave 84 contained just a buckle and beads, she was located in the middle of the cemetery and her head was laid ('pillowed') on a new-born infant; she was aged between 25 and 35 and showed workrelated pathologies: hyperplatymeric and Os acromiale (Duhig 1998: 77).

Similarly, Great Chesterford grave 2 contained a wealthy female adult (no further age given) with a great square-headed brooch, two saucer brooches and beads; she was on the edge of the cemetery and showed evidence of ante-mortem tooth loss, osteoarthritis and degenerative disc disease, the latter two of which may have been caused by work. The infant accompanying her 
was 40 weeks and placed on her right side; they were both buried on the edge of the cemetery (Evison 1994: 190; Waldron 1994: 59).

At Lechlade there were three females with foetal or neonatal remains accompanying them. All were described as deaths in childbirth by the excavator (Harman and Jones 1998: 44). Grave 95 included a seven-month foetus found in post-excavation; if disarticulated during decomposition, this individual may have been recovered only when the grave soil was sieved. Grave 95 was wealthy, she was buried with a gold disc pendent, beads and a weaving baton, she was placed in the middle of a dispersed seventh-century plot. The woman was aged 35-40 and her twelfth thoracic vertebra had partially collapsed. Grave 188 contained a woman aged 25-30 located between three plots on the same orientation as the majority of graves, with no grave goods and no pathology. The foetus was new born, slightly premature and placed on her lefthand side (Boyle et al. 1998: 134). Grave 107 contained a newborn in a furnished but not rich grave on the left of an adult aged 25-30 and buried with a box, picks, spindle whorls and animal bones. She was found in the middle of the dispersed seventh-century plot with no pathology (Boyle et al. 1998).

There are two double graves from Worthy Park. Grave 18 is of a 20-25-year-old woman with an infant on her right-hand side. She had a slight roughening on some of her left tibia and was found in the middle of the site with a single bead (Chadwick Hawkes and Granger 2003: 25-6). The skeleton in grave 21 was aged $45+$ and was found with a full-term foetus and a knife in the middle of the cemetery. The foetus was either laid on her breast or was inside her abdomen and her pelvis was largely missing, truncated by a later burial (Chadwick Hawkes and Granger 2003: 28). She showed some evidence of work-related pathology with osteochondrial lesions on her feet, marks which may have been caused by repeated squatting and bending next to an upright loom (Wells 2003).

All of these women were aged between 15 and 45+, the full range of female fertility, with the majority in their 20s and 30s. They were buried on the edge or in the middle of cemeteries, with rich, mediocre or poor grave goods. Some, but not all, showed trauma but no exotic pathologies; occasionally they manifested minor congenital abnormalities. These were not special burials but women from the whole social spectrum, and women who worked. Funeral treatment varied from cemetery to cemetery and there was no universal reaction to double maternal mortality; each funeral party negotiated its own conclusion to their personal tragedy and they buried their women with infants in family cemeteries. Despite these examples, double fatalities were probably not the normal mode of death and foetuses were also buried individually and in multi-phased pits (Evison 1994: 31). Similarly an infant could survive its mother and, if they died separately, they were probably buried separately. As a result we will never know how many, or which, women died in childbirth but, as maternal death is a significant factor in patterns of female mortality, we may get an impression of its extent from comparative mortuary demographics.

\section{Female fertility and mortuary statistics}

Some 20 per cent of modern births present difficulty but death is not usually the result (Zhu et al. 2006). In 1990 the developed world had a maternal mortality of twenty-six in 100,000 compared to an average of 400 in 100,000 for the whole world. Ninety-nine per cent of all deaths resulting from maternity took place in the developing world and one 
third of these in just two places, India and Nigeria (Wilmot and Gemmill 2012: 26). Maternal mortality is significantly higher in rural areas and in poorer communities, but these figures are not just related to geographic or economic situations where disease, diet and medicine are different from in the developed world. They are also the result of cultural circumstance, with complications in pregnancy as the highest cause of death among adolescent girls because of a preference for early fertility (Conde-Agudelo, Belizán and Lammers 2004; Patton et al. 2009).

From 570 obstetric deaths observed in a community-based study of rural Maharashtra, India, 71.9 per cent were the results of dystocia (Ganatra, Coyaji and Rao 1998). The highest probability of mortality was identified among women who were aged less than 20 with an increased risk after 35 years; the first and fifth (or further) pregnancies were the most dangerous. Not taking advantage of antenatal care, or delivery by an untrained attendant, also significantly increased the odds of death and living in a hamlet-sized (rather than village-sized) community nearly doubled the probability of mortality, although this may have been because of limited access to medical care (Ganatra, Coyaji and Rao 1998: 564). Furthermore, infant survival was diminished after maternal death (5.1 times) and the risk of infant mortality (in the first year of life) was twenty-eight times that of an infant with a living mother (Ganatra, Coyaji and Rao 1998: 565). In a second study looking at Anantapur district, India, 1073 deaths were identified, 867 in rural settings and 206 in an urban setting (Bhatia 1993). Bhatia also investigated the mortality rate by age (Fig. 3), showing an increase in the mortality of younger women due to pregnancy with a high of 31.6 per cent of deaths among those aged 20-24 years. Marai Bhat's (2002) survey of 36,993 Indian women also observed a high incidence of mortality among younger women, indicating that 40.2 per cent of deaths among woman aged 15-19 were caused by pregnancy.

To explore demographic questions in early British populations Brothwell investigated a selection of skeletal material and described the 'average lifespan' for adults in Neolithic to medieval populations, but he used small numbers and was not clear about his statistics (Brothwell 1972). He indicated that adult women had a lifespan of: Neolithic 28.3, Bronze Age 29.9, Iron Age 29.9, Saxon rural populations 33.1 and medieval rural populations 31.3

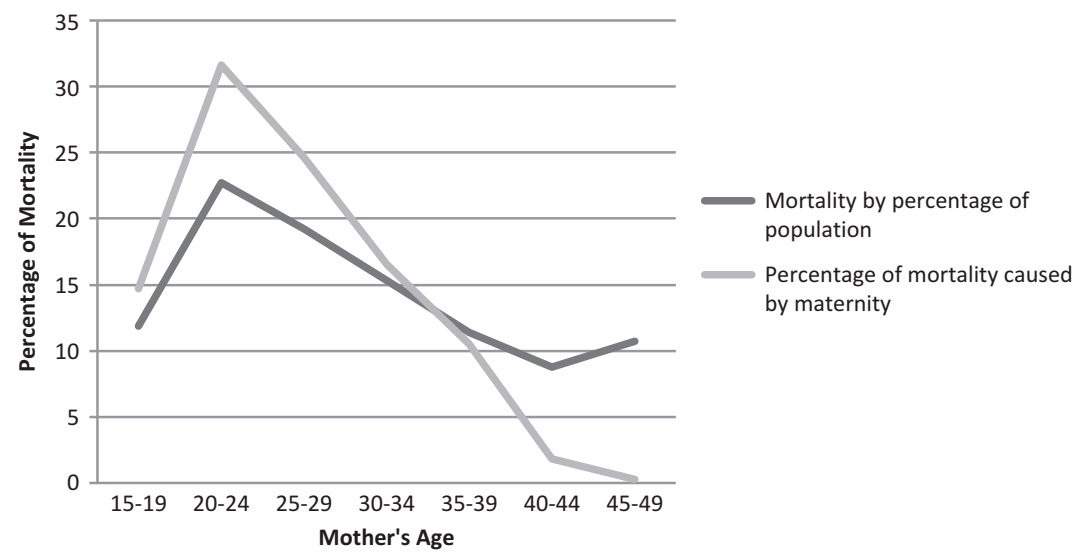

Figure 3 Maternal mortality verses mortality by percentage of population in Anantapur district, India (from Bhatia 1993: 313, table 1). 


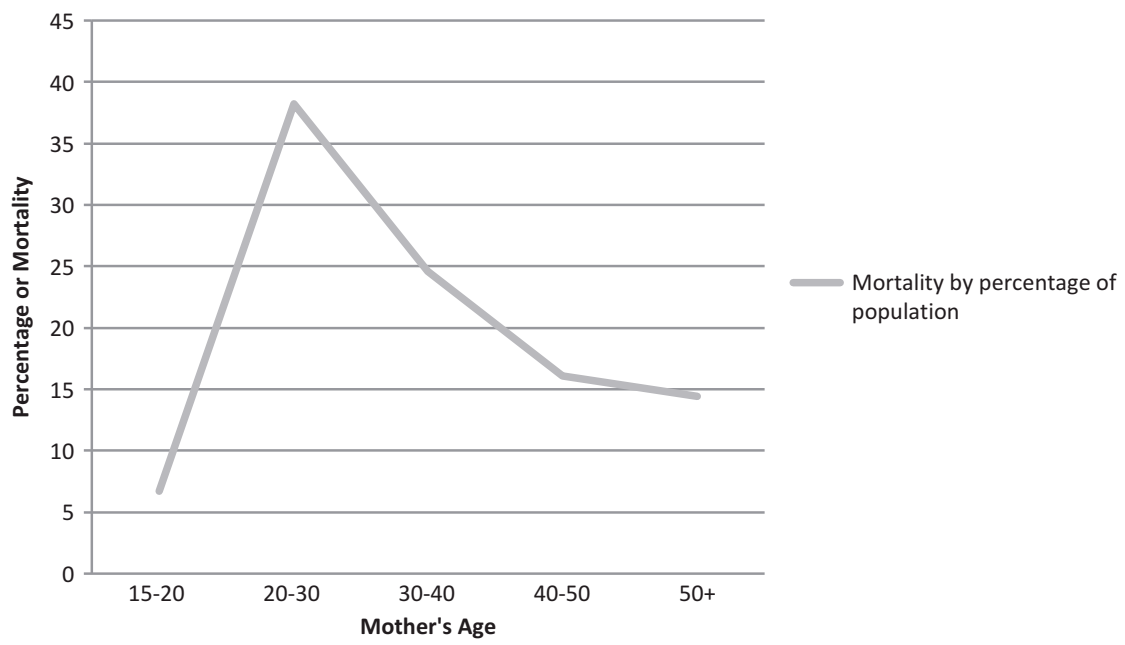

Figure 4 Mortuary profile for early Anglo-Saxon women, the graph shows age by decade against the percentage of mortality within that age group. The sample consisted of 374 female skeletons from 46 cemeteries (from Stoodley 1999, table 73).

years. However, these figures are not a reflection of life-span, which is better represented by survival statistics, but average mortality figures, which are useful when presented as a mortuary profile for age structuring (Chamberlin 2001, 2006: 28-38, 75, 90-1; Roberts 2009: 138).

Based on a more detailed study, Stoodley placed the average life expectancy of a woman at 30 (Stoodley 1999: 119). Interestingly, Stoodley also produced a mortality profile for women; one that shares the same pattern seen from India with a significant peak in the 20s (compare Fig. 3 and Fig. 4). The statistics are derived from skeletal data so suffer from a tendency to underrepresent older individuals and ignores skeletons which could not be sexed (Stoodley 1999: 106). However, the results are conspicuous, placing over 38 per cent of Anglo-Saxon female mortality into a single decade of life, a trend unlikely to be the product solely of sampling error. A pattern this striking, like the Anantapur district case study, is likely to have maternal mortality as its dynamic factor. These figures suggest that the late 20s was the period in a woman's life when she was exposed to higher risk and had either her first or fifth (and further) child. The older women, Apple Down grave 174 and Lechlade grave 95, may have survived multiple births before succumbing to the risks of child bearing, but as a result we should consider the possibility that early Anglo-Saxon women married and had their children later than we might have expected, as was the case with later medieval women (Gilchrist 2012: 38-9).

\section{Discussion}

Everyone would have known someone who had, or would, die in childbirth. Given that reality, it is conspicuous that there are not more examples of double obstetric death in the archaeological record. However, the earliest Anglo-Saxon laws to survive witness controls placed over female fertility. The laws of Ethelbert (king of Kent AD 602-3) regulated sex with women and levied fines against men 
for engaging in sex with a king's maiden, a grinding slave, a noble woman's serving-woman, a free man's serving-woman or a slave woman. They also regulated adultery, where a free man who lay with another free man's wife had to obtain a replacement. According to law 85, even a servant or slave was protected though compensation if a man lay with his wife. Laws 82 and 83 covered forced marriage and compensation for breach of betrothal and law 81 read: 'If she does not bear a child', indicating the importance of female fertility by placing the property of a childless widow into the hands of her paternal kinsmen (Whitelock 1979: 391-4). Although these are the laws of an early Christian king they are partly contemporary with the early Anglo-Saxon cemeteries and so the people interred within these places were the social agents who lived these written and cultural rules and their unwritten oral predecessors. The legal authority regulated a woman's sexual partnerships and placed emphasis on female fertility within identifiable biological lineages; adherence to these early laws was probably not enforceable but may have been cultural practice (Reynolds 2009). This system created a network of social rules, marriage restrictions and taboos which acted to control female fertility, placing emphasis on the mature body. The presence of an infant within the grave of an early Anglo-Saxon woman may not have acted as a talisman of her special or exotic status but as a symbol of her fertility, a powerful representation corresponding with inheritance strategies and family identities.

\section{Conclusion}

Death in childbirth was commonplace in Anglo-Saxon England but this does not mean that the double death of a mother and infant was not socially or emotionally difficult. Grave 57 at Oakington was a double obstetric calamity and resulted in a marginal burial location. However, this was not a universal response and women with foetuses in-utero were interred in subsidiary and central locations, with wealthy, modest and sparse sets of grave goods. Young infants were found alongside women aged 15-45+, the full range of female fertility. In all of the examples described: women did not manifest exotic pathologies, were not universally buried in marginal locations and did not exhibit the characteristics of special status, indeed, quite the opposite. Death in childbirth was a democratic tragedy affecting the whole social spectrum but the treatment of the individual was determined through local agency, the result of negotiations that took place within a particular funeral party during a specific set of chronological and social circumstances. The inclusion of an infant or foetus in the grave of a woman was a visually powerful statement aimed at the funerary party and provided testimony to female fertility nested within concepts of inheritance and identity.

Maternal mortality was far more common than Wells (1978) assumed. Post-mortem extrusion, however, is an extraordinary and implausible taphonomic process. Malpresentation, infection or blood loss will have caused the woman and foetus to die and, unfortunately, if a woman died the chances of a neonate surviving were limited. Past societies probably employed social mechanisms or cultural responses that reduced the risk of mortality. Childbirth at home, the presence of a 'midwife' or experienced person augmented deliberate planning of pregnancy through institutions like late marriage or cultural taboos. And, while it would be imprudent to consider the reproductive process as the primary agency behind marriage and sexual practice, cultural factors intersected with mortuary and fertility patterns to create demographic profiles and the archaeological traces of very human behaviours. 


\section{Acknowledgements}

The authors would like to thank Michael Wysocki and Nick Stoodley for information relating to this paper. We would also like to thank Jim Morris and Meredith Carroll for reading its drafts as well as Richard Mortimer and Faye Simpson who have been essential to the success of the Oakington project. Any remaining errors are our own.

\section{References}

Anderson, T. and K. Parfitt. 1998. 'Two Unusual Burials from Medieval Dover.' International Journal of Osteoarchaeology 8: 123-4.

Bhatia, J. C. 1993. 'Levels and Causes of Maternal Mortality in Southern India.' Studies in Family Planning 24 (5): 310-18.

Boyle, A., D. Jennings, D. Miles and S. Palmer. 1998. The Anglo-Saxon Cemetery at Butler's Field, Lechlade, Gloucestershire. Vol. 1. Oxford: Oxford Archaeological Unit.

Brothwell, D. 1972. 'Palaeodemography and Earlier British Populations.' World Archaeology 4 (1): 75-87.

Buikstra, J. E. and D. H. Ubelaker. 1994. Standards for Data Collection from Human Skeletal Remains. Fayetteville, AR: Arkansas Archeological Society.

Chadwick Hawkes, S. and G. Granger. 2003. The Anglo-Saxon Cemetery at Worthy Park, Kingsworthy. Oxford: Oxford University School of Archaeology.

Chadwick Hawkes, S. and C. Wells. 1975. 'An Anglo-Saxon Obstetric Calamity from Kingsworthy, Hampshire.' Medical and Biological Illustrations 25 (1): 47-51.

Chamberlin, A. 2001. Palaeodemography. In Handbook of Archaeological Science, edited by D. Brothwell and A. M. Pollard, 259-68. Chichester: Wiley.

Chamberlin, A. 2006. Demography in Archaeology. Cambridge: Cambridge University Press.

Conde-Agudelo, A., J. M. Belizán and C. Lammers. 2004. 'Maternal-Perinatal Morbidity and Mortality Associated with Adolescent Pregnancy in Latin America: Cross-Sectional Study.' American Journal of Obstetrics and Gynecology 192: 342-9.

Crawford, S. 2007. 'Companions, Co-Incidences or Chattels? Children and their Role in Early AngloSaxon Multiple Burials.' In Children, Childhood and Society, edited by S. Crawford. and G. Shepherd, 83-92. Oxford: BAR International Series 1696.

Down, A. and M. Welch. 1990. Chichester Excavations: Apple Down and The Mardens. Chichester: Chichester District Council.

Drinkall, G. and M. Forman. 1998. The Anglo-Saxon Cemetery at Castledyke South, Barton-on Humber. Sheffield: Sheffield Excavation Report, 6.

Duhig, C. 1998. 'The Human Skeletal Material.' In The Anglo-Saxon Cemetery at Edix Hill (Barrington A), Cambridgeshire, edited by T. Malin and J. Hines, 154-96. York: Council for British Archaeology.

Emory, P. A. and K. Wooldridge. 2011. St Pancras Burial Ground. London: Gifford Monograph.

Evison, V. I. 1987. Dover, The Buckland Anglo- Saxon Cemetery. London: Historic Buildings and Monuments Commission for England.

Evison, V. 1994. An Anglo-Saxon Cemetery at Great Chesterfield, Essex. York: Council for British Archaeology. 
Ganatra, B. R., K. J. Coyaji and V. N. Rao. 1998. 'Too Far, Too Little, Too Late: A Community-Based Case Control Study of Maternal Mortality in Rural West Maharashtra, India.' Bulletin of the World Health Organisation 76 (6): 591-98.

Garner, M. F. 2011. Interim Report on Archaeological Excavation at 69-72 St Mary Street, Southampton, (SOU 1553). Southampton: Southampton Archaeology Unit Report 1053.

Gilchrist, R. 2012. Medieval Life: Archaeology and the Life Course. Woodbridge: Boydell.

Gilchrist, R. and B. Slone. 2005. Requiem: The Medieval Monastic Cemetery in Britain. London: Museum of London Archaeology Service.

Harman, M. and E. V. Jones. 1998. 'The Human Remains.' In The Anglo Saxon Cemetery at Bulter's Field, Lechlade, Gloucester, edited by A. Boyle, D. Jennings, D. Miles and S. Palmer, 43-52. Oxford: Oxford Archaeological Unit.

Högberg, U., E. Iregren, C-H. Siven and L. Diener. 1987. 'Maternal Deaths in Medieval Sweden: An Osteological and Life Table Analysis.' Journal of Biological Science 19: 495-503.

Lee, C. 2008. 'Forever Young: Child Burial in Anglo-Saxon England.' In Youth and Age in the Medieval North, edited by S. Lewis-Simpson, 17-36. Leiden: Brill.

Leeds, E. T. and D. B. Harden. 1936. The Anglo-Saxon Cemetery at Abingdon, Berkshire. Oxford: Ashmolean Museum.

Lewis, M. 2007. The Bioarchaeology of Children: Current Perspectives in Biological and Forensic Anthropology. Cambridge: Cambridge University Press.

Lucy, S. 1999. The Anglo-Saxon way of Death. Stroud: Sutton.

Malim, T. and J. Hines. 1998. The Anglo-Saxon Cemetery at Edix Hill (Barrington A), Cambridgeshire. York: Council for British Archaeology.

Marai Bhat, P. N. 2002. 'Maternal Mortality in India: An Update.' Studies in Family Planning 33 (3): 227-36.

Patton, G. C., C. Coffey, S. M. Sawyer, R. M. Viner, D. M. Haller, K. Bose, T. Vos, J. Ferguson and C. D. Mathers. 2009. 'Global Patterns of Mortality in Young People: A Systematic Analysis of Population Health Data.' Lancet 374: 881-92.

Powers, R. and R. Cullen, 1987. 'Human Skeletal Remains.' In Dover, The Buckland Anglo- Saxon Cemetery, edited by V. I. Evison, 197-101. London: Historic Buildings and Monuments Commission for England.

Price, N. 2010. 'Passing into Poetry: Viking-Age Mortuary Drama and the Origins of Norse Mythology.' Medieval Archaeology 54: 123-56.

Reynolds, A. 2009. Anglo-Saxon Deviant Burial Customs. Oxford, Oxford University Press.

Roberts, C. 2009. Human Remains in Archaeology: A Handbook. York: Council for British Archaeology.

Roberts, C. and M. Cox, 2003. Health and Disease in Britain. Stroud: Sutton.

Sayer, D., R. Mortimer and F. Simpson. 2011. 'Anglo-Saxon Oakington: Life and Death in the East Anglian Fens.' Current Archaeology 261: 20-7.

Schulz, F., Püschel, K. and Tsokos, M. 2005. 'Postmortem Foetal Extrusion in a Case of Maternal Heroin Intoxication.' Forensic Science, Medicine and Pathology 1 (4): 273-6.

Simm, A. 2007. 'Malpresentations in Labour.' Obstetrics, Gynaecology and Reproductive Medicine 17: 10.

Smith, S. 1955. Forensic Medicine. London: J. \& A. Churchill.

Stoodley, N. 1999. The Spindle and the Spear: A Critical Enquiry into the Construction and Meaning of Gender in the Early Anglo-Saxon Burial Rite. Oxford: BAR British Series 288. 
Stoodley, N. 2002. 'Multiple Burials, Multiple Meanings? Interpreting the Early Anglo-Saxon Multiple Interment.' In Burial in Early Medieval England and Wales, edited by S. Lucy and A. Reynolds, 103-21. Leeds: Society for Medieval Archaeology.

Vennemann, B., M. Bohnert, S. Pollak and M. G. Perdekamp. 2008. 'Postmortem "Delivery" in a Pregnant Fire Victim.' International Journal of Legal Medicine 122 (4): 327-31.

Wainwright, G. J. 1979. Gussage All Saints: An Iron Age Settlement in Dorset. London: HMSO.

Waldron, A. W. 1994. 'The Human Remains.' In An Anglo-Saxon Cemetery at Great Chesterfield, Essex, edited by V. I. Evison, 52-65. York: Council for British Archaeology.

Wells, C. 1978. 'A Medieval Burial of a Pregnant Woman.' The Practitioner 221: 442-3.

Wells, C. 2003. 'Other Pathology.' In The Anglo-Saxon Cemetery at Worthy Park, Kingsworthy, edited by S. Chadwick Hawkes and G. Granger, 165-76. Oxford: Oxford University School of Archaeology.

Whitelock, D. 1979. English Historical Documents, Vol. 1, c.500-1042. London: Methuen.

Williams, H. 2006. Death and Memory in Early Medieval Britain. Cambridge: Cambridge University Press.

Wilmot, J. and A. Gemmill. 2012. Trends in Maternal Mortality: 1990-2010. Geneva: World Health Organisation.

Wood, J. W., G. R. Milner and H. C. Harpending. 1992. 'The Osteological Paradox: Problems of Inferring Prehistoric Health from Skeletal Samples.' Current Anthropology 33 (4): 343-70.

Zhu, B. P., V. Grigorescu, T. Le, M. Lin, G. Copeland, M. Barone and G. Turabelidze. 2006. 'Labour Dystocia and its Association with Interpregnancy Interval.' American Journal of Obstetrics and Gynecology 85: 810-14.

Duncan Sayer is a lecturer in archaeology at the University of Central Lancashire. He has published widely on funerary and Anglo-Saxon archaeology. He is the author of Ethics and Burial Archaeology, and co-editor of Mortuary Practice and Social Identity in the Middle Ages and The Archaeology of Post Medieval Religion.

Sam Dickinson is a research student at the University of Central Lancashire and the osteoarchaeolgist for the Oakington project. Her research focuses on the lived, bodily experience of women and children in early Anglo-Saxon England. 